UDC 811.111

DOI https://doi.org/10.32838/2710-4656/2021.5-1/44

Lymar M. Yu.

Petro Mohyla Black Sea National University

\title{
ENGLISH ABBREVIATIONS AND ACRONYMS IN THE SOCIO-POLITICAL DISCOURSE: TYPES AND APPROACHES IN TRANSLATION
}

The article pays significant attention to the peculiarities and types of English abbreviations and acronyms. It also considers the shortenings in the socio-political discourse that is insufficiently explored field for domestic linguists. Given the fact that the circulation of information forces to look for effective ways of its transfer, storage and remembering, especially, in socio-political communication, this study is purposed at exploring specifics and differences of English shortenings, since understanding of them creates a necessary basis for the further study of new trends in their forming and translating into Ukrainian. Here, descriptive-analytical method, the method of continuous sampling and the comparative analysis are used.

The study summarizes that abbreviation is a compound word formed by the first letters or other parts of words that are components of the name or the concept and acronym is understood as an abbreviation consisting of the first letters of each word in the name of something, pronounced as a word. There are various classifications of abbreviations according to different criteria. Generally, there four main types of abbreviations in English, - initialisms, shortenings, contractions and acronyms, - that are used in socio-political discourse. The article also represents several types of acronyms, including backronyms, sound, letter-sound and recursive ones. Methods of forming abbreviations include truncation, clipping, portmanteau or blending, etc. Understanding the ways of forming and the thematic context (background) of abbreviations and acronyms makes it possible to translate them adequately. The following approaches in translation are identified as the most effective: direct translating the full form of the abbreviation; finding of the equivalent shortenings in the target language; transcoding; using of descriptive translation; and transcoding of the appropriate abbreviation's full form.

Key words: abbreviation, acronym, initialism, shortening, socio-political discourse.

Introduction. With the beginning of the intensive development of mass media, sharing information and simultaneous tendency to stiffness of information, recently, there has been growing interest to different types of shortenings that have already become convenient means of propaganda and advertising. They make it easier to remember long names and at the same time functioning foreign names without the need to deploy or to explain them. From the beginning of the XXI century, the English language is experiencing a "neological boom" that confirms the constant change of language and its modernization [2, p. 93]. Simplified language units help to save communicative space and to convey more information.

Abbreviation (or shortening) serves as a kind of word-forming, the result of which is the emerge of new types of shortenings that serve for fixation new or renewed lexical units, such as the names of political parties, public organizations, establishments, etc. A central issue of this research is to analyse the types of English abbreviations and acronyms and their functioning in the language. Although considerable researches have been devoted to the problem of shortenings in the language, rather less attention has been paid to such fundamental questions as the problem of the word structure and its meaning, the problem of morpheme, etc.

Analysis of the latest research on the discussed issue. The aspect of translation of different types of shortenings has always been actual, and nowadays it is the sphere of interest for many scholars, especially taking into consideration the emerging number of shortenings in the social sphere of life. The problems of reduced lexical units as a specific linguistic phenomenon in modern languages attract the attention of many researchers, who focus on the features of abbreviations and their use in texts of different directions. For example, N. Zerkina, N. Kostina, and S. Pitina are exploring the ways to form shortenings [14]. I. Mischynska explores abbreviations and acronyms in economic and business-discourse 
[5]. I. Karamysheva focuses on studying of abbreviations in modern media-discourse [4]. At the same time, there are researchers, for example, L. Chumak [7] and T. Nikolaeva [6], who study the universal characteristics of acronyms and abbreviations. The basic theory of peculiarities and types of abbreviations and shortenings are also presented in the works of such scholars as O. Humboldt, O. Potebnya, N. Arutyunova, V. Maslova, and Yu. Stepanov. Mogilevsky, Yu. Amosova, Yu. Stepanov, V. Borisov, I. Arnold and others.

Nowadays, it may be noticed the increasing number of shortenings that is explained by the fact that the modern life is characterized by fast pace of life, changes in the sphere of political, scientific and cultural environment, and also by the intensification of development of mass communication and the increasing number of information. In this regard, the main task of the article is to explore specifics and differences of English abbreviations and acronyms, and their translation in socio-political context, which remains the wide research field for domestic linguists.

Methods. The comparative analysis of the structural, semantic and functional peculiarities of the English abbreviations and acronyms is used in the current research. It gave us the possibility to compare the above mentioned lexical units and to define their peculiarities in the aspect of their functioning in the language. The method of the quantitative analysis was used to determine the quantitative results of the study, which made it possible to identify the peculiarities of both usage and rendering abbreviations and acronyms from English into Ukrainian. The descriptive-analytical method and the method of continuous sampling were also used in this research for presenting its results. The object of the present study was abbreviations and acronyms in the English language.

Statement regarding the basic material of the research. First, it should be noted that abbreviations and words should not be equated. Words differs from abbreviations regardless of the complexity of their semantic structure [14, p. 138]. Abbreviations and words have common features; nevertheless, abbreviations still have their own specific character. Therefore, it is reasonable to consider the units of abbreviations not as equivalents of words, but as linguistic units that correspond to words.

The analysis of scientific literature on the topic showed that abbreviation is one of the most productive ways of word-forming. Abbreviation (Italian abbreviatura or Latin abbrevio means short) is a compound word formed by the first letters or other parts of words that are components of the name or concept, which occur not only in modern texts, but also in ancient manuscripts. The history of modern abbreviations goes back to ancient times of Marcus Tullius Cicero. His slave and personal secretary Tiro invented more than 4000 symbols to denote dates, names, legal terms and other important concepts. In the medieval period, the Tiro system of symbols was taught in European monasteries and had about 13000 symbols and signs. In English, some Tiro's symbols are still used today, in particular \& (et) which is used to mean and. In Old English manuscripts \& could have different phonetic and morphological meanings. Over time, the Tiro system was gradually replaced by new developments.

Thus, abbreviation is the process of creating new words by the means of reducing (cutting) a stem of a word, which results in forming new words with not full, reduced stem (or stems) called abbreviations. There are many types and classifications of shortenings and abbreviations according to different criteria. In this study, the most universal are observed. Generally, there four main types of abbreviations in English: initialisms, shortenings, contractions and acronyms.

According to the classification of all types of abbreviations (shortenings) proposed by Karaban, initialisms, contractions and acronyms belong to the group of lexical abbreviations [3]. Lexical abbreviations are units of speech that have not only the sound form, but also a clearly defined meaning. These are units of language that exist in the language as something already established and only voiced in the language. There is a mixed type of lexical abbreviations, which during translation become either half-alphabetisms or half-acronyms. Another type of the mixed ones is a lexem, where one of the components is the initial, and the second is a full-fledged word (A-bombatomic bomb; V-day - Victory Day).

Initialisms or alphabetisms. This category is formed by the first letters of words in the abbreviated phrase, but the finished abbreviation does not sound like a new word. It also includes traditional abbreviations of country names or other proper names (the $U S A$ - the United States of America; EU - the European Union, the UK - the United Kingdom). Each letter in initialism is pronounced separately. Practically, such abbreviations are often used for convenience, situationally, for thematic speeches or in the context of specific research, etc. If such abbreviation as the FBI (Federal Bureau of Investigation) is well known and usually does not cause misunderstandings, then $C A$ (Consular Affairs) or PD (Public Diplomacy Section) can be deciphered only by understanding to which sphere they belong. 
Initialisms are often called acronyms because of their common principle of reduction, omitting the fact that the latter more often form new words. This is a very narrow approach. Addressing this misunderstanding, researchers use the refinement of word acronyms to distinguish simple initial abbreviations from the very acronyms.

Shortenings. This is the way of word-forming, when a part of a stem is cut or end of the word has been omitted (app - application; champ - champion; pro professional; memo - memorandum; APPAL - Appalachian State Low Level Radioactive Waste Commission). This part of a stem either matches a word, or is a phrase connected by the general content. Shortenings are created by using such techniques as truncation (includes only of the first part of a word: Mon., Apr., Oct.); clipping (includes the middle part or end of a word: phone - telephone, biz - business); portmanteau (blending of several words: ID card = identification + card, telecast $=$ television + broadcast; Eurasia $=$ Europa + Asia Franglais $=$ Frankais + Anglais; Spanglish $=$ Spanish + English $;$ Hindlish $=$ Hindi + English) [7, p. 202; 9, p. 210, 213]. Such well-known researchers as Voloshin, Levkivska, Mogilev and others investigate the relationships between the sound and the meaning of shortenings. The solution of this issue defines whether a shortening is recognized as independent lexical units or not.

Referring to the classification of Karaban, we can mention graphic (half-shortenings) and syntactic types of shortenings [3]. Within graphic shortenings there are understand the one used only in a written language; they do not have their own special sound form, which is implemented in an oral language (Con . - Conservative Party; Free. - Freedom Party; Lbl. - Liberal Party; Unr. - Unenrolled). Syntactic (dotted, hyphenated, slashed, italic, zero and combined) shortening consist of letters and numbers (Am. I'st-America First Party; $C-20$ - Committee of 20). It can switch from an informal, colloquial language to an official one, in the case when one of the components loses its total value and receives a narrower meaning. A group of syntactic shortenings is represented by elliptical abbreviations, characterized by the omission of one of the components, and the remaining component does not carry any change in its morpheme structure. It only "condenses" the semantics of the entire phrase.

Contractions. This type involves omitting a letter from the middle of a word ( $\mathrm{Dr}$ - Doctor; govt government; opnl-operational). No full stop is used at the end of such abbreviations. Contractions can be formed by aphesis or dropping the unstressed vowel at the beginning of a word: cause instead of because, bout instead of about. Such contracted words are not widely used in socio-political texts because of their informal shade.

Acronyms. In the process of language development, abbreviations can be transformed into acronyms, especially if they are well-known and widely used. Abbreviations and acronyms are shortened forms of words; however, there is a difference. Thus, the online "Cambridge Dictionary" gives one of the best and universal definitions to these terms: 1) abbreviation [ə,bri..vi'er.fon] is a short form of a word or phrase; 2) acronym ['æk.rə.nIm] is an abbreviation consisting of the first letters of each word in the name of something, pronounced as a word [8]. Despite the fact that acronyms are often called any abbreviations formed by initial letters, the most popular manuals, including "Fowler's Dictionary of Modern English Usage", "Chicago Manual of Style", "Bryson's Dictionary of Troublesome Words", "Garner's Modern American Usage", and "The New York Times Manual of Style and Usage", stress that acronyms are only those abbreviations, which are pronounced or spelled as a single word - not by letters. "All acronyms can be abbreviations, but all abbreviations cannot be acronyms" [11, p. 13]. In other words, an acronym is a subcategory of an abbreviation.

There are different opinions concerning the use of the term acronym. On the one hand, acronyms are any words composed of the first letters or parts of words in an abbreviated phrase, on the other hand - only those shortenings that are pronounced as whole words and not as a sequence of letters' names. Most often, an acronym embodies a sound abbreviation. Diuzhykova defines several types of acronyms, including sound, letter-sound, backronyms (bacronym) and recursive ones [1, p. 114]. Sound acronym is created from the initial words of an original phrase (UNESCO - United Nations Educational, Scientific and Cultural Organization; UNIDO - United Nations Industrial Development Organization). Letter-sound is formed partly from the names of initial letters and partly - from the initial sounds of original phrase's words (JPEG [dzeI peg] - Joint Photographic Experts Group; SFMOMA [es ef' movmə] - San Francisco Museum of Modern Art). Backronym is existing words/abbreviations, which acquire new decryptions (TEAM - time, energy and money; together everyone achieves more, etc.). Finally, recursive is an abbreviation that is a part of decryption (FARM - Farm Animal Rights Movement; VISA - Visa International Service Association). In order to make abbreviation become an acronym, it must be given a sufficient number of vowel sounds, be readable and sonorous. 
Acronyms also include abbreviations, complex terms, formed by combining the initial parts of the phrase words (syllable-based), the formation of terms by the method of adhesion or the union of two words and combining them into one (Benelux - Belgium, the Netherlands and Luxembourg; Brexit - British exit; MARAD - Maritime Administration). There are so-called homo-acronyms or homonymic acronyms that are now becoming widespread. Due to the very close relationship between oral and written forms of speech, sometimes, it is very difficult to distinguish the shortenings created in oral speech from graphic abbreviations. Moreover, the latter are increasingly appearing in oral speech and are widely used in communication. However, lexical units formed by combining the initial letter or letters from each of the consecutive parts of the phrase that are written and read as a regular English word are called acronyms.

There are a number of acronyms that repeat words, which are already included in the core literal abbreviation: HIV virus - human immunodeficiency virus; ICBM missile - intercontinental ballistic missile; VIP person - very important person, and so on. Recently, scientists also distinguish this type of shortenings as tautological that are phrases in which one word duplicates the same or synonymous word already marked in abbreviation, and thus forms a tautology.

Approaches in translation. Abbreviations and acronyms in socio-political texts are translated in a similar way to abbreviations in other areas. For an accurate translation, it is necessary to have a good understanding of the background, as the same shortenings may have different interpretations. For example, G6 and $G 7$ could be translated as шостий and сьомий ранги, if they are deciphered as Grade 6 and Grade 7 in the context of civil service [10]. Nevertheless, these shortenings could be understood as Велика шістка and Велика сімка in the international political context, since $G 6$ and $G 7$ mean the Group of Six (the former name) and the Group of Seven (the current name) - an informal international club that unites Great Britain, Germany, Italy, Canada, France, Japan and the USA. On the same principle, the USA could be translated as Сполучені Штати Америки or армія США; RUS - російський (Russian) or Сільська служба з надання комунальних послуг (Rural Utilities Service) [13].

There are several options for translating abbreviations. First, a translator can refer to the full form of the abbreviation and translate it: govt - (government) - уряд; BrStd - (British Standard) - британський стандарт; G7 - (the Group of Seven) - Група семи ог Велика сімка. Second, equivalent shortenings could be used: $P C$ (personal computer) - ПК (персональний комп'ютер); FBI (Federal Bureau of Investigation) - ФБР (Федеральне бюро розслідувань); CIS (the Commonwealth of Independent States) - СНД (Співдружність Незалежних Держав); UNO (United Nations Organisation) - ООН (Організація Об'єднаних Націй); IAEA (International Atomic Energy Agency) - МАГАТЕ (Міжнародне агентство з атомної енергіi). Transcoding is the third approach: NATO (North Atlantic Treaty Organization) - НАТО (Організація Північноатлантичного договору); ASEAN (Association of South East Asia Nations) - ACEAH (Асоціація держав Південно-Східної Азії); IUPAC (International Union of Pure and Applied Chemistry) - IЮПАК (Міжнародний союз теоретичної і прикладної xiмiï). Fourth, a translator can use descriptive translation: INAD (Inadmissible Passenger) - особа, якій відповідними органами відмовлено у праві на в'їзд до держави; G/TIP (Office to Monitor and Combat Trafficking in Persons) - Відділ моніторингу та протидії торгівлі людьми (author's translation). Finally, one more approach is transcoding of the appropriate abbreviation's full form (usually used for translating the names of media agencies, publishing editions and so on): BBC (British Broadcasting Corporation) - агентство Бі-Бі-Сi; CNN (Cable News Network) - агентство Ci-Ен-Ен.

Conclusions. Abbreviations (initialisms, shortenings, contractions and acronyms) are compound words formed by the first letters or other parts of words that are widely used in oral and written speech. Acronym is understood as an abbreviation consisting of the first letters of each word in the name of something, pronounced as a word. This is the key difference between these types of shortenings. In other words, an acronym is a subcategory of an abbreviation.

There are different opinions concerning the use of the term acronym. On the one hand, acronyms are any words composed of the first letters or parts of words in an abbreviated phrase, on the other hand only those shortenings that are pronounced as whole words and not as a sequence of letters' names. Most often, an acronym embodies a sound abbreviation. There are main types of acronyms, including backronyms, sound, letter-sound and recursive acronyms. They are widely used in political, socio-political and business texts. They can be the names of positions, organizations, agreements, etc. The principle of their formation mostly corresponds to the general principles of shortenings' formation. 
Understanding the ways of forming abbreviations and acronyms makes it possible to translate them correctly that is extremely important for the interpretation of foreign texts and the ability to discuss politically and socially important topics. Thus, studying of abbreviations and their variations seems significant in linguistic theory and practice.

\section{References:}

1. Дюжикова Е. Аббревиация сравнительно с словосложением : структура и семантика : дис. ... докт. фил. наук: 10.02.04. Москва, 1997. 350 с.

2. Єнікєєва С. М. Скорочення слова як механізм формотворення та словотворення в сучасній англійській мові. Вісник Житомирського держсавного ун-ту ім. І. Франка. 2006. Вип. 27. С. 93-99.

3. Карабан В. Посібник-довідник з перекладу англійської літератури на українську мову. Київ : Політична думка, $1997.300 \mathrm{c}$.

4. Карамишева I. Структурна та функціональна характеристика абревіатур у сучасному медіадискурсі (на матеріалі статей BВC та CNN). Актуальні питання гуманітарних наук. 2020. Вип. 31. Т. 2. С. $28-34$. DOI: $10.24919 / 2308-4863.2 / 31.213836$.

5. Міщинська I. Абревіатури та акроніми в економічному та бізнес-дискурсі. Філологічний дискурс. 2018. Вип. 7. С. 221-227.

6. Ніколаєва Т. Перекладацькі аспекти сучасних англійських абревіацій. Науковий вісник Міжнародного гуманітарного університету. Серія «Філологія». 2018. № 37. Т. 3. С. 107-110.

7. Чумак Л. Акроніми як форма скорочень складної лексичної одиниці. Сучасна англістика: Стереотипність i творчість : тези доповідей Всеукраїнського наукового форуму. Харків : Торсінг Плюс, 2006. C. 201-203.

8. Cambridge dictionary. Cambridge University Press, 2021. URL: https://dictionary.cambridge.org/ (дата звернення: 19.09.2021).

9. Devereux R. Shortenings, blendings and acronyms. Word Ways. 1984. Vol. 17. Iss. 4. P. 210-215.

10. Grade structures of the civil service. URL: https://www.instituteforgovernment.org.uk/explainers/gradestructures-civil-service (дата звернення: 19.09.2021).

11. Key to party abbreviations. The Washington Post, 2021. URL: https://www.washingtonpost.com/wp-srv/ onpolitics/elections/2001/results/parties.htm (дата звернення: 19.09.2021).

12. Pujiyanti A., Senowarsito, Ardini S. Analysis of acronym and abbreviations in IJAL journal. Journal of English Language Learning (JELL). 2019. Vol. 3. № 2. P. 9-21.

13. The United States governmental manual. Commonly used agency acronyms. URL: https://www.govinfo. gov/content/pkg/GOVMAN-2015-07-01/pdf/GOVMAN-2015-07-01-Commonly-Used-Agency-Acronyms-105. pdf (дата звернення: 19.09.2021).

14. Zerkina N., Kostina N., Pitina S. Abbreviation semantics. Procedia - Social and Behavioral Sciences. 2015. Vol. 199. P. 137-142. DOI: 10.1016/j.sbspro.2015.07.497.

\section{Лимар М. Ю. АБРЕВІАТУРИ Й АКРОНІМИ В АНГЛОМОВНОМУ СУСПІЛЬНО-ПОЛІТИЧНОМУ ДИСКУРСІ: ВИДИ І ПІДХОДИ В ПЕРЕКЛАДІ}

У статті значна увага приділяється особливостям та типам англійських абревіатур $і$ акронімів. Також проаналізовано скорочення в суспільно-політичному дискурсі, щз є малодослідженим полем для вітчизняних лінгвістів. 3 огляду на той факт, що обіг інформачії спонукає до пошуків ефективних шляхів ї̈ передачі, зберігання та запам'ятовування, ие дослідження має на меті вивчення особливостей та відмінностей англійських скорочень, оскільки їх розуміння створює необхідну основу для подальшого виявлення нових тенденцій їх формування та перекладу українською мовою. У дослідженні застосовуються описово-аналітичний метод, метод вибірки та порівняльного аналізу, що дозволяе визначити особливості скорочень і абревіатур, їх функиіонування, специфіку перекладу.

Результати дослідження підтвердили, що абревіатура - ие складна лексична одиничя, утворена першими літерами або іншими частинами слів, які єскладовими частинами назви або поняття. У свою чергу, акронім можна вважати абревіатурою, що не лише складається з перших літер кожного слова в назві, але й може вимовлятися як самостійне слово. Наявні різні підходи до класифікаиії типів абревіатур і акронімів. У статті представлено найпоширеніші з них. Загалом, є чотири основні типи скорочень в англійській мові, - ініціалізми, власне скорочення, усічення й абревіатури, - що використовуються в суспільно-політичному дискурсі. У статті також представлено декілька типів акронім, а саме звукові, буквено-звукові, рекурсивні та бекроніми. Методи формування скорочень включають усічення, урізання, змішування тощо. Розуміння тематичного контексту абревіатур і акронімів, способів їх утворення сприяє їх адекватному перекладу. Найбільш ефективними визнано такі підходи в перекладі: прямий переклад повної форми абревіатури; знаходження еквівалентних скорочень у мові перекладу; перекодування; використання описового перекладу; перекодування повної форми відповідної абревіатури.

Ключові слова: абревіатура, акронім, інічіалізм, усічення, суспільно-політичний дискурс. 